\title{
NASILENIE ZABURZEŃ DEPRESYJNYCH WŚRÓD PACJENTÓW ONKOLOGICZNYCH
}

\section{DEPRESSION INTENSIFICATION IN ONCOLOGICAL PATIENTS}

\author{
Ewa Humeniuk $^{1(\mathrm{~A}, \mathrm{E})}$, Olga Dąbska ${ }^{1(\mathrm{D}, \mathrm{E}, \mathrm{F})}$, Aleksandra Krupa ${ }^{1(\mathrm{~B}, \mathrm{C}, \mathrm{D})}$
}

${ }^{1}$ Uniwersytet Medyczny w Lublinie, Wydział Nauk o Zdrowiu, Zakład Patologii i Rehabilitacji Mowy

\begin{abstract}
Humeniuk, E., Dąbska, O., Krupa, A. (2018). Nasilenie zaburzeń depresyjnych wśród pacjentów onkologicznych. Rozprawy Społeczne, 12(3), 55-63. https://doi.org/10.29316/rs.2018.21
\end{abstract}

Wkład autorów:

A. Zaplanowanie badań

B. Zebranie danych

C. Dane - analiza i statystyki

D. Interpretacja danych

E. Przygotowanie artykułu

F. Wyszukiwanie i analiza

literatury

G. Zebranie funduszy
Tabele: 6

Ryciny: 1

Literatura: 37

Otrzymano: czerwiec 2017

Zaakceptowano: listopad 2017

\begin{abstract}
Streszczenie
Wstęp. W pracy dokonano oceny występowania depresji wśród osób leczonych z powodu choroby nowotworowej w zależności od uzyskiwanego wsparcia społecznego i realizowanego stylu życia.

Materiał i metody. Grupę badaną stanowiło 63 pacjentów onkologicznych. Posłużono się metodą sondażu diagnostycznego, techniką ankietową. Obecność i stopień nasilenia objawów depresji badano Inwentarzem Objawów Depresyjnych Becka, który uzupełniono autorskim kwestionariuszem analizującym sytuację socjo-demograficzną i rodzinną ankietowanych, uzyskiwane wsparcie i realizowany styl życia.

Wyniki. Wykazano występowanie depresji umiarkowanej u ponad połowy respondentów (54\%), a u blisko $1 / 10$ ciężką formę tego zaburzenia. Tylko $1 / 3$ badanych nie doświadczała objawów depresji i uskarżała się wyłącznie na obniżenie nastroju.

Wnioski. Nasilenie objawów depresyjnych łączyło się z doświadczaniem przykrych emocji, pesymistyczną wizją przyszłości, trudnościami w porozumieniu z bliskimi na płaszczyźnie emocjonalnej. Badani w niewielkim stopniu deklarowali korzystanie ze specjalistycznej pomocy psychologa czy psychiatry. Z racji częstego współwystępowania depresji i chorób nowotworowych pacjenci onkologiczni powinni być objęci holistyczną opieką, uwzględniającą sytuację emocjonalną chorych.
\end{abstract}

Słowa kluczowe: choroba nowotworowa, zaburzenia afektywne, depresja

\section{Summary}

Introduction. The article describes assessment of depression occurrence in cancer patients in relation to the received social support and patients' lifestyle.

Material and methods. The research group consisted of 63 oncological patients. A diagnostic poll was used as a survey technique. The occurrence and intensity level of depression symptoms were measured following the Beck Depression Inventory (BDI), which was accompanied by the author's questionnaire analyzing the family situation of the surveyed, as well as the received support and their lifestyle.

Results. The analysis conducted with the help of the BDI questionnaire presented the following results: more than half of the surveyed (54\%) suffered from moderate depression and roughly $1 / 10$ of the respondents suffered from severe depression. Only $1 / 3$ of the surveyed showed no signs of depression and complained only about low mood.

Conclusions. The severity of depressive symptoms was associated with the experience of unpleasant emotions, pessimistic vision of the future, difficulties in consultation with relatives on an emotional level. Very few of the respondents consulted psychologists and psychiatrists. Because cancer and depression often coincide, oncological patients should be taken under holistic care which would tend to their emotional situation.

Keywords: cancer, affective disorders, depression

\section{Wstęp}

Diagnoza choroby somatycznej wymieniana jest, jako częste uwarunkowanie rozwoju zaburzeń psychicznych. Liczne są doniesienia wskazujące na częstsze występowanie objawów depresyjnych w grupie osób zmagających się z chorobami somatycznymi w porównaniu z generalną populacją (Dudek, Siwek, 2007). Między zaburzeniami depresyjnymi, a chorobami fizycznymi obserwuje się dwukierunkową zależność. Mianowicie, z jednej strony choroba somatyczna predysponuje do wystąpienia depresji,

\footnotetext{
Adres korespondencyjny: Olga Dąbska, Uniwersytet Medyczny w Lublinie, Wydział Nauk o Zdrowiu, Zakład Patologii i Rehabilitacji Mowy, ul. Staszica 4-6 p. 212,20-081 Lublin, e-mail: olga.dabska@umlub.pl, tel.: 814486792 Copyright by: Państwowa Szkoła Wyższa im. Papieża Jana Pawła II w Białej Podlaskiej, Ewa Humeniuk, Olga Dąbska, Aleksandra Krupa 
z drugiej zaś depresja zwiększa ryzyko rozwoju choroby somatycznej (Jarema, Rabe-Jabłońska, 2011).

Choroby nowotworowe są jednym $\mathrm{z}$ wiodących problemów zdrowotnych na całym świecie. Rozpoznanie nowotworu stanowi czynnik silnie obniżający jakość życia pacjentów we wszystkich jego wymiarach (Zielińska-Więczkowska, Betłakowski, 2010). Analiza zależności między funkcjonowaniem psychofizycznym i psychospołecznym stanowi obecnie często podejmowany temat badań ośrodków naukowych z całego świata (Jabłoński, Furgał, Dudek, Zięba, 2008). Najczęściej spotykanym wśród pacjentów onkologicznych zaburzeniem psychicznym jest depresja (Rolińska, Furmaga, Kwaśniewski, Makara-Studzińska, 2011). „Pomimo dużego rozpowszechnienia tych zaburzeń, tylko 20 proc. z nich jest prawidłowo rozpoznawanych" (Nowicki, Rzadkowska, 2005, s. 397). Z danych przedstawionych przez Sharpe i in. wśród chorych na nowotwór, którym towarzyszy depresja tylko wobec $42 \%$ podejmowane jest specjalistyczne leczenie, przy czym skuteczność terapii zauważalna jest tylko u 15\% (Sharpe, Strong, Allen, 2004). Stany depresyjne w grupie osób cierpiących na choroby nowotworowe występują średnio 4 razy częściej w porównaniu z populacją ogólną (Ślubowska, Ślubowski, 2008).

Nowotwór to jedna z chorób generująca bardzo silne przeżycia traumatyczne. Pacjenci doświadczają przygnębienia, żalu, złości, gniewu, poczucia małowartościowości, winy, lęku. U podstaw tych reakcji zdaniem Kopczyńskiej-Tyszko leży silny stres powstały na skutek rozpoznania choroby, niepewności rokowania, niedostatecznego wsparcia społecznego, złych stosunków z personelem medycznym, współistniejące trudne wydarzenia życiowe, niepożądane skutki terapii (Kopczyńska-Tyszko, 1999). Z kolei Jarosz wpływu choroby na stan psychiczny człowieka upatruje w oddziaływaniu środowiska życia, pracy, warunkach fizycznych, cechach osobowości, przebiegu procesu chorobowego, towarzyszących mu dolegliwości i wynikających z niego ograniczeń (Jarosz, 1971). Powstawanie i przebieg depresji wśród pacjentów onkologicznych determinowany jest wieloczynnikowo, toteż wymienić należy także młody wiek, utratę samodzielności, niemożność pełnienia dotychczasowych ról społecznych, poczucie zagrożenia życia, rodzaj otrzymywanego leczenia, doznawany ból fizyczny, brak poczucia kontroli nad przebiegiem choroby, hospitalizację, zmiany w wyglądzie zewnętrznym (Rolińska i in., 2011; Ohnish, 2011; Stępień, Trypka, 2012). Szerokie spektrum determinantów zaburzeń depresyjnych w przebiegu choroby nowotworowej potwierdzają Nowicki i Rządkowska zdaniem, których „Przyczyną są zarówno zmiany biologiczne, zachodzące w organizmie, jak i czynniki społeczne" (Nowicki, Rządkowska, 2005, s. 396).

Celem pracy była ocena występowania depresji wśród osób leczonych z powodu choroby nowotworowej w zależności od uzyskiwanego wsparcia społecznego i realizowanego stylu życia.

\section{Materiał i metody}

Grupę badaną stanowiło 63 pacjentów leczonych z powodu choroby nowotworowej w Top-Medical Sp. $z$ o.o. w Lublinie i Centrum Wielospecjalistycznej Opieki Ambulatoryjnej NZOZ MARMED w Świdniku. Ankietowani byli w wieku 23-74 lata, przy czym średnia wieku wynosiła 48,32 $\pm 11,92$ lata. Zdecydowaną większość grupy stanowiły kobiety $(97 \%$, $\mathrm{n}=61)$, mieszkańcy miast $(81 \%, \mathrm{n}=51)$, osoby zamężne $(60 \%, n=38)$. Blisko połowa respondentów posiadała średnie wykształcenie $(49 \%, n=31)$. W ocenie $57 \%(n=36)$ badanych ich sytuacja materialna jest przeciętna. Badani chorowali przeważnie na nowotwór złośliwy $(87 \%, n=55)$. Choroba zlokalizowana była m.in. w obrębie piersi $(46 \%, n=29)$, macicy $(12 \%, n=8)$, płuca $(6 \%, n=4)$, tarczycy $(5 \%, n=3)$, jelita grubego $(5 \%, n=3)$ i innych narządów. Szczegółową charakterystykę socjo-demograficzną badanej grupy przedstawiono $\mathrm{w}$ tabeli 1 .

Tabela 1. Szczegółowa socjo-demograficzna charakterystyka badanej grupy

\begin{tabular}{|c|c|c|c|}
\hline \multirow{2}{*}{\multicolumn{2}{|c|}{ Zmiennan }} & \multicolumn{2}{|c|}{$\begin{array}{c}\text { Wartości } \\
\text { analizowanych } \\
\text { parametrów }\end{array}$} \\
\hline & & $\%$ & \\
\hline \multirow{2}{*}{ Płeć } & kobiety & 61 & 97 \\
\hline & mężczyźni & 2 & 3 \\
\hline \multirow{3}{*}{ Grupa wiekowa } & do 40 lat & 17 & 27 \\
\hline & 41-55 lat & 24 & 38 \\
\hline & powyżej 55 lat & 22 & 35 \\
\hline \multirow{2}{*}{$\begin{array}{c}\text { Miejsce } \\
\text { zamieszkania }\end{array}$} & miasto & 51 & 81 \\
\hline & wieś & 12 & 19 \\
\hline \multirow{4}{*}{ Stan cywilny } & $\begin{array}{l}\text { w związku } \\
\text { małżeńskim }\end{array}$ & 38 & 60 \\
\hline & panna, kawaler & 6 & 10 \\
\hline & rozwiedziony/a & 13 & 20 \\
\hline & owdowiały/a & 6 & 10 \\
\hline \multirow{4}{*}{$\begin{array}{c}\text { Poziom } \\
\text { wykształcenia }\end{array}$} & $\begin{array}{c}\text { podstawowe, } \\
\text { zawodowe }\end{array}$ & 11 & 18 \\
\hline & średnie & 31 & 49 \\
\hline & $\begin{array}{l}\text { niepełne } \\
\text { wyższe }\end{array}$ & 7 & 11 \\
\hline & wyższe & 14 & 22 \\
\hline \multirow{2}{*}{$\begin{array}{l}\text { Aktywność } \\
\text { zawodowa }\end{array}$} & tak & 21 & 33 \\
\hline & nie & 42 & 67 \\
\hline \multirow{3}{*}{$\begin{array}{c}\text { Sytuacja } \\
\text { finansowa }\end{array}$} & $\begin{array}{c}\text { dobra, bardzo } \\
\text { dobra }\end{array}$ & 13 & 20 \\
\hline & przeciętna & 36 & 57 \\
\hline & zła & 14 & 23 \\
\hline \multirow{3}{*}{ Typ nowotworu } & złośliwy & 55 & 87 \\
\hline & $\begin{array}{c}\text { miejscowo } \\
\text { złośliwy }\end{array}$ & 5 & 8 \\
\hline & łagodny & 3 & 5 \\
\hline
\end{tabular}

Źródło: opracowanie własne. 
Narzędziem badawczym był Inwentarz Objawów Depresyjnych Becka (BDI) autorstwa Aarona Temkina Becka, w polskiej adaptacji Parnowskiego i Jernajczyka. W Inwentarzu BDI umieszczonych zostało 21 objawów depresji, ocenianych na skali czterostopniowej, w której 0 oznacza brak danego objawu, a 3 wskazuje na duże nasilenie objawu. Wśród objawów uwzględniono: smutek, przygnębienie, pesymizm, zaniedbania, utrata odczuwania przyjemności i zainteresowań, w tym seksem, poczucie winy i poniesienia kary, odczuwanie niechęci do własnej osoby, wysoki samokrytycyzm myśli samobójcze, płacz, zdenerwowanie, trudności w podejmowaniu decyzji, niskie poczucie własnej wartości, spadek energii, zaburzenia snu i apetytu, rozdrażnienie, osłabienie organizmu, zmęczenie (Zawadzki, Popiel, Pragłowska, 2009). Badany może uzyskać 0-63 punktów, przy czym im wyższa jest ich ilość, tym nasilenie objawów depresji jest większe. Interpretacja punktacji jest następująca: $\leq 10$ punktów - brak depresji, lekkie zaburzenia nastroju, 11-27 punktów - umiarkowana depresja, $\geq 27$ punktów - głęboka depresja (Zając, 2014). Dotychczas przeprowadzone badania wskazują na bardzo dużą rzetelność i trafność polskiej wersji kwestionariusza, którą uznaje się za w pełni porównywalną z wersją oryginalną, dlatego też rekomenduje się ją do stosowania $w$ badaniach naukowych i klinicznych w Polsce (Zawadzki i in., 2009). Ponadto użyto autorski kwestionariusz, składający się z pytań zamkniętych $\mathrm{w}$ formie alternatywnych i koniunktywnych. Pytania dotyczyły sytuacji socjo-demograficznej, rodzinnej ankietowanego, uzyskiwanego wsparcia i realizowanego stylu życia.
Badania miały charakter dobrowolny, indywidualny, anonimowy. Zostały przeprowadzone zgodnie z założeniami Deklaracji Helsińskiej. Ankietowanych poinformowano o celu i przebiegu badań. Analizy materiału badawczego dokonano przy użyciu pakietu statystycznego STATISTICA 12 i programu Microsoft Office Excel. Przyjęto poziom istotności p $<0,05$, wskazujący na istotne statystycznie różnice bądź zależności. Wartości analizowanych parametrów niemierzalnych przedstawiono przy pomocy liczności i odsetka. Dla niepowiązanych cech jakościowych do wykrycia istnienia różnic między porównywanymi grupami użyto testu jednorodności $\mathrm{Ch}^{2}$. Do zbadania istnienia zależności między badanymi cechami użyto testu niezależności $\mathrm{Ch}^{2}$. Do oceny czynników ryzyka wystąpienia umiarkowanej lub ciężkiej depresji wykorzystano analizę Pareto.

\section{Wyniki}

Średnia ocena poziomu depresji dla całej analizowanej próby wyniosła 14,33 $\pm 10,47$ (zakres 0-49 punktów). Tylko $1 /{ }_{3}(\mathrm{n}=22)$ badanych nie doświadczała objawów depresji i uskarżała się wyłącznie na obniżenie nastroju. U ponad połowy respondentów (54\%, n=34) stwierdzono depresję umiarkowaną, a u blisko $1 /{ }_{10}(n=7)$ ciężką. Na podstawie analizy Pareto stwierdzono, że wystapienie umiarkowanej lub ciężkiej depresji w dużym stopniu determinowały obecność nowotworu złośliwego, uciążliwe efekty uboczne choroby, ograniczenie aktywności fizycznej, negatywne odczucia w trakcie leczenia, dolegliwości towarzyszące chorobie, brak możliwości wykonywania dotychczasowych obowiązków zawodowych czy rozmowy o troskach i obawach z rodziną [rycina 1].

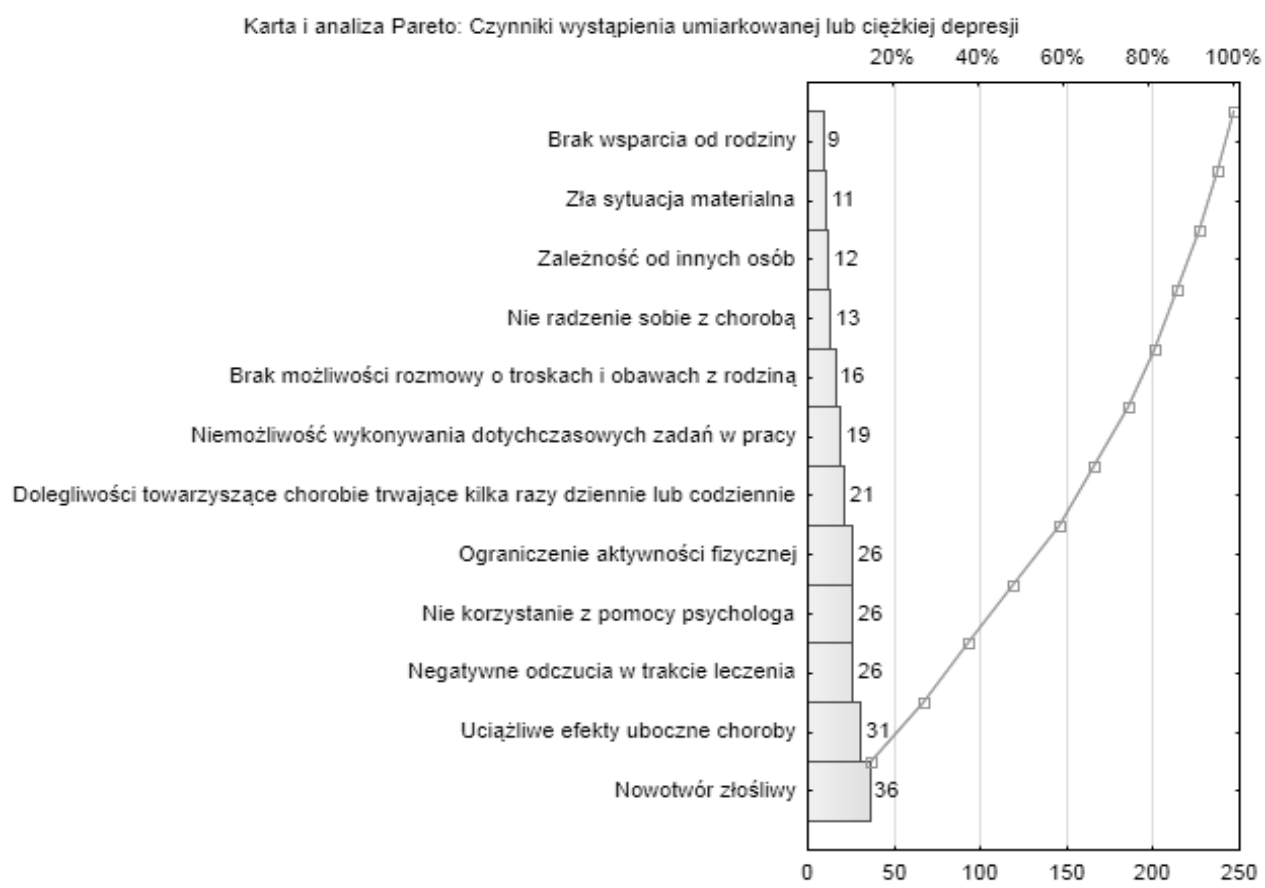

Rycina 1. Czynniki sprzyjające wystąpieniu umiarkowanej lub ciężkiej depresji w grupie pacjentów onkologicznych Źródło: opracowanie własne. 
W przeważającej większości $(83 \%, \mathrm{n}=52)$ ankietowani po zdiagnozowaniu choroby nowotworowej dokonali zmian $\mathrm{w}$ dotychczas realizowanym stylu życia. Osoby te (69\%) nieznacznie częściej deklarowały objawy umiarkowanej lub ciężkiej depresji $\mathrm{w}$ porównaniu $\mathrm{z}$ badanymi, którzy nie zmienili swojego stylu życia (45\%). Stwierdzone różnice nie były istotne statystycznie $(p=0,13)$ [tabela 2]. Ankietowani przekształcając styl życia koncentrowali się m.in. na stałe kontrole stanu zdrowia $(83 \%$, $\mathrm{n}=43)$, unikanie sytuacji stresowych $(48 \%, \mathrm{n}=25)$, rezygnację $\mathrm{z}$ używek $(23 \%, \mathrm{n}=12)$. W związku z rozpoznaniem choroby $\mathrm{w}$ życiu przeważającej części ankietowanych wystąpiło ograniczenie aktywności fizycznej (78\%), rezygnacja lub ograniczenie pracy zawodowej (54\%). Blisko $1 /{ }_{3}$ zależna była od osób trzecich, a $\mathrm{u}^{1} /{ }_{10}$ nastąpiły zmiany $\mathrm{w}$ pełnionych rolach społecznych.

Tabela 2. Występowanie depresji w zależności od zmiany stylu życia podczas leczenia

\begin{tabular}{|c|c|c|c|}
\hline \multirow{2}{*}{$\begin{array}{l}\text { Zmiana stylu życia po } \\
\text { zdiagnozowaniu choroby } \\
\text { brak / obniżenie nastroju }\end{array}$} & \multicolumn{2}{|c|}{$\begin{array}{c}\text { Występowanie } \\
\text { depresji }\end{array}$} \\
\cline { 3 - 4 } & $\begin{array}{c}\text { umiar- } \\
\text { kowana } \\
\text { / ciężka }\end{array}$ & \\
\hline \multirow{2}{*}{ tak } & $\mathrm{n}$ & 16 & 36 \\
\cline { 2 - 4 } & $\%$ & 31 & 69 \\
\hline \multirow{2}{*}{ nie } & $\mathrm{n}$ & 6 & 5 \\
\cline { 2 - 4 } & $\%$ & 55 & 45 \\
\hline
\end{tabular}

Analiza statystyczna: $\mathrm{Chi}^{2}=2,26 ; \mathrm{p}=0,13$

$\mathbf{n}$ - liczebność, \% - odsetek, p - poziom istotności statystycznej, $\mathbf{C h i}^{2}$ - wynik testu Chi-kwadrat Źródło: opracowanie własne.

Analiza wykazała, że blisko połowa badanych doświadczała pozytywnych odczuć w trakcie leczenia i była pełna nadziei $(46 \%, n=29)$. Pozostali odczuwali poczucie bezsensu życia $(5 \%, n=3)$ lub bycia ciężarem dla innych $(8 \%, n=5)$,obawiali się o rodzinę $(24 \%, n=15)$, wskazali na brak nadziei na wyleczenie $(10 \%, n=6)$. Diagnozie towarzyszyły także negatywne emocje, jak lęk (57\%), strach przed skutkami leczenia (41\%), smutek (36\%), gniew (29\%) i poczucie wstydu (3\%). Stwierdzono istotną statystycznie zależność między obecnością doznawania przykrych odczuć, a występowaniem depresji $(p=0,04)$. Ankietowani, doświadczający negatywnych odczuć podczas leczenia częściej deklarowali umiarkowaną lub ciężką depresję (76\%) w porównaniu z badanymi o pozytywnych odczuciach (52\%) [tabela 3].
Tabela 3. Występowanie depresji w zależności od charakteru doświadczanych odczuć podczas leczenia

\begin{tabular}{|c|c|c|c|}
\hline \multirow{2}{*}{$\begin{array}{c}\text { Rodzaj odczuć } \\
\text { brak / obniżenie nastroju }\end{array}$} & \multicolumn{2}{c|}{$\begin{array}{c}\text { Występowanie } \\
\text { depresji }\end{array}$} \\
\cline { 3 - 4 } \multicolumn{2}{|c|}{$\begin{array}{c}\text { umiar- } \\
\text { kowana } \\
\text { / ciężka }\end{array}$} & \\
\hline \multirow{2}{*}{ pozytywne } & $\mathrm{n}$ & 14 & 15 \\
\cline { 2 - 4 } & $\%$ & 48 & 52 \\
\hline negatywne & $\mathrm{n}$ & 8 & 26 \\
\cline { 2 - 4 } & $\%$ & 24 & 76 \\
\hline
\end{tabular}

Analiza statystyczna: $\mathrm{Chi}^{2}=4,22 ; \mathrm{p}=0,04$

$\mathbf{n}$ - liczebność, \% - odsetek, $\mathbf{p}$ - poziom istotności statystycznej, $\mathbf{C h i}^{2}$ - wynik testu Chi-kwadrat

Źródło: opracowanie własne.

Większość ankietowanych uważała, że pokona nowotwór i zrealizuje swoje marzenia $(65 \%, n=41)$. Pozostali twierdzili, że nie spotka ich już nic dobrego $(3 \%, n=2)$, przyznali, iż diagnoza choroby nowotworowej pozbawiła ich planów i marzeń $(17 \%, n=11)$ lub nie zastanawiali się nad swoją przyszłością (14\%, $\mathrm{n}=9$ ). Stwierdzono istotne statystycznie zależności między postrzeganiem przyszłości przez chorych, a występowaniem depresji $(p=0,01)$. Ankietowani, którzy negatywnie myśleli o swojej przyszłości $(100 \%)$ znacznie częściej cierpieli na umiarkowaną lub ciężką depresję w porównaniu z badanymi, wykazującymi pozytywne myślenie (56\%) lub niezastanawiającymi się nad przyszłością (56\%) [tabela 4].

Tabela 4. Występowanie depresji w zależności od postrzegania swojej przyszłości

\begin{tabular}{|c|c|c|c|}
\hline \multirow{2}{*}{\multicolumn{2}{|c|}{$\begin{array}{c}\text { Postrzeganie swojej przyszłości } \\
\text { brak / obniżenie nastroju }\end{array}$}} & \multicolumn{2}{|c|}{$\begin{array}{c}\text { Występowanie } \\
\text { depresji }\end{array}$} \\
\hline & & \multirow{2}{*}{$\begin{array}{c}\begin{array}{c}\text { umiar- } \\
\text { kowana } \\
\text { / ciężka }\end{array} \\
4\end{array}$} & \multirow[b]{2}{*}{ 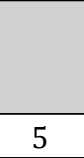 } \\
\hline \multirow{2}{*}{$\begin{array}{c}\text { nie zastanawiałem/am się nad } \\
\text { przyszłością }\end{array}$} & $\mathrm{n}$ & & \\
\hline & $\%$ & 44 & 56 \\
\hline \multirow{2}{*}{$\begin{array}{c}\text { pokonam nowotwór i zreali- } \\
\text { zuje swoje marzenia }\end{array}$} & $\mathrm{n}$ & 18 & 23 \\
\hline & $\%$ & 44 & 56 \\
\hline \multirow{2}{*}{$\begin{array}{l}\text { diagnoza choroby pozbawiła } \\
\text { mnie planów i marzeń; myślę, } \\
\text { że nic dobrego mnie już nie } \\
\text { spotka }\end{array}$} & $\mathrm{n}$ & 0 & 13 \\
\hline & $\%$ & 0 & 100 \\
\hline \multicolumn{4}{|c|}{ Analiza statystyczna: $\mathrm{Chi}^{2}=8,79 ; \mathrm{p}=0,01$} \\
\hline \multicolumn{4}{|c|}{$\begin{array}{c}\mathbf{n} \text { - liczebność, \% - odsetek, p - poziom istotności staty- } \\
\text { stycznej, } \mathbf{C h i}^{\mathbf{2}} \text { - wynik testu Chi-kwadrat }\end{array}$} \\
\hline
\end{tabular}

Źródło: opracowanie własne.

Ankietowani przeważni rozmawiali o swoich obawach i troskach $\mathrm{z}$ członkami rodziny (71\%, $\mathrm{n}=45)$. Pozostała grupa nie miała rodziny lub nie podejmowała $\mathrm{z}$ najbliższymi tematu choroby. Respondenci, nierozmawiający $\mathrm{z}$ rodziną o swoich troskach, obawach (89\%) częściej doświadczali umiarkowanej lub ciężkiej depresji w porównaniu z badanymi, którzy takie rozmowy prowadzili 
(56\%). Stwierdzone różnice były istotne statystycznie $(\mathrm{p}=0,01)$ [tabela 5].

Tabela 5. Występowanie depresji w zależności od podejmowania rozmowy z bliskimi na temat swoich obaw, trosk

\begin{tabular}{|c|c|c|c|}
\hline \multirow{2}{*}{$\begin{array}{c}\text { Rozmowa z bliskimi } \\
\text { brak / obniżenie nastroju }\end{array}$} & \multicolumn{2}{|c}{$\begin{array}{c}\text { Występowanie } \\
\text { depresji }\end{array}$} \\
\cline { 3 - 4 } & $\begin{array}{c}\text { umiar- } \\
\text { kowana } \\
\text { / ciężka }\end{array}$ & \\
\hline \multirow{2}{*}{ tak } & $\mathrm{n}$ & 20 & 25 \\
\cline { 2 - 4 } & $\%$ & 44 & 56 \\
\hline \multirow{2}{*}{ nie, nie dotyczy } & $\mathrm{n}$ & 2 & 16 \\
\cline { 2 - 4 } & $\%$ & 11 & 89 \\
\hline
\end{tabular}

Analiza statystyczna: $\mathrm{Chi}^{2}=6,29 ; \mathrm{p}=0,01$

$\mathbf{n}$ - liczebność, \% - odsetek, $\mathbf{p}$ - poziom istotności statystycznej, $\mathbf{C h i}^{2}$ - wynik testu Chi-kwadrat

Źródło: opracowanie własne.

Za najważniejsze źródło wsparcia badani uznawali rodzinę $(65 \%, \mathrm{n}=41)$ i przyjaciół $(11 \%, \mathrm{n}=7)$. $\mathrm{Z}$ badań wynika, że $84 \%(\mathrm{n}=53)$ ankietowanych deklarowało otrzymywanie wsparcia od rodziny. Znacznie niżej doceniali wsparcie okazane przez lekarza, innych pacjentów, psychologa, osoby duchownej. Uzyskano bliskie istotności statystycznej zależności między otrzymywaniem wsparcia od rodziny, a doświadczaniem depresji $(\mathrm{p}=0,07)$. Zauważono, że osoby nieotrzymujące wsparcia ze strony rodziny częściej cierpiały na umiarkowaną lub ciężką depresję $(90 \%)$ w porównaniu z badanymi, którzy takie wsparcie uzyskiwali (60\%) [tabela 6].

Tabela 6. Występowanie depresji w zależności od otrzymywania wsparcia od rodziny i korzystania z pomocy psychologa

\begin{tabular}{|c|c|c|c|}
\hline \multirow{2}{*}{\multicolumn{2}{|c|}{$\begin{array}{c}\text { Zmienna } \\
\text { brak / obniżenie nastroju }\end{array}$}} & \multicolumn{2}{|c|}{$\begin{array}{c}\text { Występowanie } \\
\text { depresji }\end{array}$} \\
\hline & & $\begin{array}{l}\text { umiar- } \\
\text { kowana } \\
\text { / ciężka }\end{array}$ & \\
\hline \multicolumn{4}{|c|}{ Otrzymywanie wsparcia od rodziny } \\
\hline \multirow{2}{*}{ tak } & $\mathrm{n}$ & 21 & 32 \\
\hline & $\%$ & 40 & 60 \\
\hline \multirow{2}{*}{ nie } & $\mathrm{n}$ & 1 & 9 \\
\hline & $\%$ & 10 & 90 \\
\hline \multicolumn{4}{|c|}{ Analiza statystyczna: $\mathrm{Chi}^{2}=3,25 ; \mathrm{p}=0,07$} \\
\hline \multicolumn{4}{|c|}{$\begin{array}{c}\mathbf{n} \text { - liczebność, } \% \text { - od setek, } \mathbf{p} \text { - poziom istotności staty- } \\
\text { stycznej, } \mathbf{C h i}^{2} \text { - wynik testu Chi-kwadrat }\end{array}$} \\
\hline
\end{tabular}

Oprócz otrzymywanego od najbliższych wsparcia respondenci przyznali, że $\mathrm{w}$ walce $\mathrm{z}$ chorobą pomocne były m.in. wiedza o chorobie, stanowiąca podstawę kontroli poznawczej wobec trudnej sytuacji $(32 \%, n=20)$, spotkania towarzyskie $(6 \%, n=4))$, hobby, skupienie się na planach i marzeniach $(11 \%$, $\mathrm{n}=7$ ). Z przeprowadzonych badań wynika także, iż większość respondentów nie korzystała z pomocy psychologa lub psychoonkologa $(68 \%, n=43)$.

\section{Dyskusja}

Zarówno specyficzny charakter choroby nowotworowej, jak i procesu jej leczenia sprawiają, że chorzy doświadczają zazwyczaj przykrych stanów emocjonalnych (Olszewski, 2006). „Nadal najczęstszym i najwcześniej pojawiającym się stanem towarzyszącym chorym jest lęk, będący pewnym tłem, zaczątkiem innych przeżyć i stanów, jak depresja, różne formy agresji, radość, nadzieja" (Adamczyk, Makara-Studzińska, Sidor, Pucek, Wdowiak, 2014, s. 70). W przeważającej części pacjentom towarzyszą negatywne odczucia, jak zmęczenie, niepokój, bezsilność, niezrozumienie, strach, gniew, smutek, rozgoryczenie, rozdrażnienie, panika, obawa (Szwat, Słupski, Krzyżanowski, 2011; Kieszkowska-Grudny, 2012). Nadmierne ich nasilenie w niekorzystny sposób wpływa na proces leczenia, gdyż osłabia motywację, zaangażowane i wolę walki chorego. Utrudnia adaptację pacjenta do sytuacji, w której obecnie się znajduje. Predysponuje do izolacji społecznej, kryzysu duchowego, utraty autonomii i kontroli (Krawczyk, 2013). Dochodzi do ogólnego obniżenia nastroju, odczucia bezbronności, bezradności, beznadziejności (Massie, 2004). Ponadto „Lęk i depresja często uznawane są za czynniki generujące ból lub nasilające go" (Cepuch, Wordliczek, 2006, s. 44). Jednakże największy wpływ na powstawanie zaburzeń depresyjnych w przebiegu choroby nowotworowej mają składowe triady depresyjnej tj. negatywne myśli o sobie, otaczającej rzeczywistości oraz przyszłości. Grupa 46\% ankietowanych w autorskiej analizie odczuwała nadzieję w związku z podjętym leczeniem. Pozostali doświadczali poczucia bezsensu życia, bycia ciężarem dla innych, obawy o rodzinę, braku nadziei na wyleczenie. Diagnoza generowała u badanych negatywne emocje, jak lęk, strach, smutek, gniew i poczucie wstydu.

Amirifard i in. badali związek między inteligencją emocjonalną, a zdrowiem psychicznym i mechanizmami radzenia sobie $\mathrm{z}$ chorobą u pacjentów onkologicznych. Zaobserwowali odwrotną zależność między lękiem, a kontrolą stresu oraz istotny związek między depresją, a ogólnym nastrojem i adaptacją do choroby (Amirifard i in., 2017). Kulpa i in. oceniali wpływ akceptacji choroby nowotworowej na jakość życia pacjentów. Zauważyli, że osoby wykazujące ducha walki, pozytywne nastawienie, konstruktywne metody redukowania stresu i przystosowania do choroby lepiej funkcjonowały w obszarach relacji fizycznych, emocjonalnych, poznawczych i społecznych oraz deklarowały lepszą ogólną jakość życia. Z kolei wyższe natężenie lęku, bezradności, beznadziejności obniżało deklarowaną jakość życia. Badacze potwierdzają wpływ adaptacji psychicznej do choroby na jakość życia pacjenta (Kulpa, Owczarek, Stypuła-Ciuba, 2013). Malicka i in. oceniali nastrój i identyfikowali wzorce radzenia sobie z chorobą u kobiet po leczeniu raka piersi (NP) i nowotworów narządów rodnych (NNR). Objawy obniżonego nastroju wskazywało $40 \%$ bada- 
nej grupy, w tym ponad połowa pacjentek (55\%) po operacji w obrębie narządów rodnych oraz $1 / 4$ kobiet po mastektomii. Wysokie wyniki kwestionariusza $B D I$, świadczące o rozpoznaniu depresji pozostają w związku z silnym, lękowym zaabsorbowaniem chorobą, bezradnością, beznadziejnością, destrukcyjnym stylem radzenia sobie $\mathrm{z}$ chorobą. $\mathrm{Z}$ kolei niski wynik BDI koreluje wyraźnie z duchem walki, pozytywnym przewartościowaniem i konstruktywnym stylem radzenia sobie z chorobą (Malicka, Szczepańska, Anioł, Rymaszewska, Woźniewski, 2009). Mansano-Schlosser i in. donoszą, iż w analizowanej grupie kobiet $\mathrm{z}$ rakiem piersi aż 58,9\% skarżyło się na zaburzenia snu, a 27,2\% wykazywało objawy umiarkowanej lub ciężkiej formy depresji. Znaczące korelacje stwierdzono między nadzieją i jakością snu, a depresją. Zdaniem badaczy wysoki poziom nadziei, niska depresyjność i brak zaburzeń snu poprawia jakość życia pacjentek (Mansano-Schlosser, Ceolim, Valerio, 2017). Stutzman i Abraham uważają, że pacjenci o niskim poziomie tzw. dobrostan, który można rozumieć jako dobre samopoczucie częściej wykazują wyższe natężenie objawów depresyjnych (Stutzman, Abraham, 2017). Na podstawie badań własnych stwierdzono istotną statystycznie zależność między rodzajem doznawanych odczuć, a występowaniem depresji $(\mathrm{p}=0,04)$. Ankietowani, doświadczający negatywnych odczuć podczas leczenia częściej deklarowali umiarkowaną lub ciężką depresję (76\%) w porównaniu z badanymi o pozytywnych odczuciach (52\%). Wyniki własnych badań i doniesienia z badań innych autorów podkreślają ogromny wpływ doświadczanych emocji i odczuć na przebieg procesu terapeutycznego i wystąpienie zaburzeń depresyjnych wśród pacjentów onkologicznych.

Konsekwencją rozpoznania choroby nowotworowej często są zmiany w obrębie wzorców zachowań, zwłaszcza w zakresie codziennej aktywności społecznej, życia rodzinnego, towarzyskiego, zawodowego. Dochodzi do osłabienia uwagi i koncentracji, zaniżenia samooceny, braku wiary w siebie i swoje możliwości, anhedonii (zaburzeń odczuwania przyjemności), nasilenia poczucia winy, wycofania z życia społecznego, pesymistycznych wizji przyszłości, myśli samobójczych, zaburzeń snu i odżywiania (Rymaszewska, 2008; Orońska, 2004). Chorzy „(...) na raka doświadczają pogorszenia się stanu zdrowia i samopoczucia, degradacji swojej roli zawodowej i rodzinnej, zauważają niekorzystną zmianę swojego wyglądu, ich przyszłość wydaje się skracać" (Dębski, Kulik, 2004, s. 3). Badane przez Pawlik i Karczmarek-Borowską kobiety po mastektomii w 75,93\% deklarowały akceptację swojej choroby. Czuły się potrzebne (42,59\%), niezależne $(31,48 \%)$, nie postrzegały siebie, jako ciężaru dla innych $(53,70 \%)$, uważały się za pełnowartościowe $(44,44 \%)$ i samowystarczalne $(27,78 \%)$. Mimo to aż $1 / 3$ nie była w stanie określić, czy ich choroba wprowadza w zakłopotanie innych ludzi (Pawlik, Karczmarek-Borowska, 2013). Z kolei uczestnicz- ki sondażu ankietowego przeprowadzonego przez Nowickiego i Ostrowską chore na raka piersi wykazywały niższy poziom akceptacji choroby (44\%), lecz częściej czuły się potrzebne (80\%) i niezależne $(67 \%)$ (Nowicki, Ostrowska, 2008). W związku $\mathrm{z}$ rozpoznaniem choroby nowotworowej w grupie ankietowanych $w$ ramach autorskiej analizy w życiu przeważającej części wystąpiło ograniczenie aktywności fizycznej, rezygnacja lub ograniczenie pracy zawodowej, pojawiła się zależność od osób trzecich, zmianie uległy pełnione dotychczas role społeczne. W przeważającej większości ankietowani po zdiagnozowaniu choroby nowotworowej dokonali zmian w dotychczas realizowanym stylu życia. Mimo, że nie odnotowano istotnej statystycznie zależności między zmianą dotychczasowego stylu życia, a nasileniem objawów depresyjnych osoby, które dokonywały zmian w swoim życiu nieznacznie częściej deklarowały objawy umiarkowanej lub ciężkiej depresji w porównaniu z badanymi, którzy nie zmienili swojego stylu życia.

W badaniach Baczewskiej i in. ponad połowa pacjentów onkologicznych nie skarżyła się na smutek i przygnębienie $(54,90 \%)$, nie przejmowała nazbyt przyszłością $(58,82 \%)$, nie czuła się winnym wobec siebie lub innych (50\%). Natomiast badani deklarowali duże trudności $\mathrm{z}$ podejmowaniem decyzji $(71,57 \%)$, snem $(72,55 \%)$, zamartwiali się wyglądem $(65,69 \%)$ (Baczewska, Kropornicka, Drozd, Olszak, 2013). W badaniach Sobieralskiej-Michalak i in. tylko jedna kobieta chora na raka piersi nie wykazywała motywacji do walki z chorobą, dwie ujawniały trudności w pogodzeniu się z chorobą, bezradność, strach, niepokój. Pozostałe deklarowały przystosowanie się do życia $\mathrm{z}$ chorobą, realizując konstruktywny styl radzenia sobie (Sobieralska-Michalak, Kowalska, Tudorowska, 2016). Wśród badanych przez Grabińską i in. nadzieje na pełne wyleczenie przejawiała połowa grupy. Ankietowani liczyli także w dużej mierze na wydłużenie życia i poprawę jego jakości. Nadzieja na pełne wyleczenie częściej występowała w grupie osób leczonych po raz pierwszy. Osoby z nawrotem choroby częściej deklarowały nadzieję na wydłużenie życia (Grabińska, Szewczyk -Cisek, Hernik, Mykała-Cieśla, Kaziród, 2011). Większość ankietowanych w ramach autorskiej analizy deklarowało pozytywne nastawienie i postawę do obecnej sytuacji. Twierdzili, że pokonają nowotwór i zrealizują swoje marzenia. Natomiast 14\% nie zastanawiało się nad swoją przyszłością. Pozostali wykazywali pesymistyczne nastawienie, twierdzili, że nie spotka ich już nic dobrego, przyznali, iż diagnoza choroby nowotworowej pozbawiła ich planów i marzeń. Stwierdzono istotną statystycznie zależność między postrzeganiem przyszłości przez chorych, a występowaniem depresji $(p=0,01)$. Ankietowani, którzy negatywnie myśleli o swojej przyszłości $(100 \%)$ znacznie częściej cierpieli na umiarkowaną lub ciężką depresję w porównaniu z badanymi, wykazującymi pozytywne myślenie (56\%) lub niezastanawiającymi się nad przyszłością (56\%). 
W sytuacji zmagania się z chorobą wielu pacjentów prócz wsparcia ze strony personelu medycznego może liczyć na pomoc rodziny w przezwyciężeniu choroby. Wsparcie społeczne rzutuje pozytywnie na jakość życia chorego, jego kondycję psychiczną i radzenie sobie $\mathrm{z}$ chorobą nowotworową. Potwierdzają to Nmeth i in., którzy badając poziom wsparcia społecznego wśród pacjentów onkologicznych wykazali, iż kobiety mające dzieci i partnera czuły się psychicznie lepiej niżeli te samotne. Zdaniem badaczy chorzy lepiej radzą sobie z chorobą, gdy doświadczają emocjonalnego oraz instrumentalnego wsparcia od najbliższych (Nmeth i in., 2011). de Walden-Gałuszko i in. zaobserwowali, iż na nasilenie objawów depresyjnych wpływa znacząco otrzymywane wsparcie społeczne. Pacjenci onkologiczni, którzy nie doświadczali takiego wsparcia znacznie częściej $(47,9 \%)$ cierpieli na zespół depresyjny endogenny w porównaniu $z$ osobami oceniającymi okazywane wsparcie jako średnie $(22,9 \%)$ czy duże $(29,1 \%)$ (de Walden-Gałuszko, Majkowicz, Zdun-Ryżewska, 2013). Prawie wszyscy pacjenci (98\%) badani przez Grabińską i in. mogli liczyć na wsparcie przyjaciół i rodziny (Grabińska i in., 2011). Na podstawie analizy własnych badań można stwierdzić, że pozytywnym faktem jest wysoki poziom wsparcia społecznego deklarowany przez ankietowanych (84\%). Za najważniejsze wsparcie ankietowani postrzegali to uzyskiwane ze strony członków rodziny i przyjaciół. Uzyskano bliskie istotności statystycznej zależności między otrzymywaniem wsparcia od rodziny, a doświadczaniem depresji $(\mathrm{p}=0,07)$. Zauważono, że osoby nieotrzymujące wsparcia najbliższych częściej cierpieli na umiarkowaną lub ciężką depresję (90\%) w porównaniu z badanymi, którzy je uzyskiwali (60\%). Za najważniejszą formę wsparcia społecznego uznano możliwość rozmowy o swoich obawach i troskach z członkami rodziny. Respondenci, nierozmawiający z rodziną o swoich troskach, obawach (89\%) częściej doświadczali umiarkowanej lub ciężkiej depresji w porównaniu z badanymi, którzy takie rozmowy prowadzili (56\%). Stwierdzone różnice były istotne statystycznie $(p=0,01)$.

Grabińska i in. analizowali zapotrzebowanie na pomoc psychologiczną u pacjentów onkologicznych z Oddziału Chorób Wewnętrznych i Chemioterapii Onkologicznej Śląskiego Uniwersytetu Medycznego w Katowicach. Przed rozpoznaniem choroby nowotworowej blisko $1 / 3$ ankietowanych deklarowała zaburzenia nastroju i stany lękowe. Tylko 33\% z tej grupy korzystało ze specjalistycznej pomocy psychologa i psychiatry. Od momentu rozpoznania choroby już $69 \%$ respondentów przyznało, że odczuwa spadek nastroju i zaburzenia lękowe. W przypadku tej grupy po specjalistyczną pomoc sięgnęło 42\%. Pozostali pacjenci nie zdecydowali się na skorzystanie $z$ porady psychologa czy psychiatry, nie wiedzieli gdzie szukać takiej pomocy, uznali ją za zbyteczną. Większość ankietowanych postrzegała pomoc psychologiczną za korzystną i pozytywnie wpływającą na tolerancję i efekty leczenia onkologicznego. Respondenci korzystali ponadto $\mathrm{z}$ technik wspierających leczenie onkologiczne, takich jak relaksacja, wizualizacja, grupy wsparcia. Jednakże o wymienionych technikach nigdy nie słyszało aż $45 \%$ badanych. Badacze wskazują, że diagnoza choroby nowotworowej determinuje wystąpienie zaburzeń psychicznych u pacjentów onkologicznych (Grabińska i in., 2011). Na praktyczny charakter wsparcia społecznego wskazują Sęk i Cieślak. Owe wsparcie może przybierać postać wymiany informacji oraz porad ze strony pracowników ochrony zdrowia i osób będących w podobnej sytuacji. Uzyskane wsparcie i wiedza zwiększają zdaniem badaczy poczucie kontroli nad zdrowiem, sprzyjają aktywnej postawie w walce $\mathrm{z}$ nowotworem (Sęk, Cieślak, 2004). W badaniach własnych znacznie niżej od wparcia ze strony rodziny i przyjaciół oceniono wsparcie okazane przez lekarza, innych pacjentów, psychologa, osoby duchownej. Większość respondentów nie korzystała z pomocy psychologa lub psychoonkologa (68\%). Za pomocne w walce $\mathrm{z}$ chorobą ankietowani uznali podnoszenie wiedzy o chorobie, spotykania z innymi pacjentami onkologicznymi, skupiało się na hobby, planach i marzeniach.

\section{Wnioski}

1. Przeprowadzona za pomocą kwestionariusza $B D I$ analiza wykazała występowanie depresji umiarkowanej u ponad połowy respondentów (54\%, $n=34)$, a u blisko ${ }^{1} / 10(n=7)$ ciężką formę tego zaburzenia. Tylko $1 \%(\mathrm{n}=22)$ badanych nie doświadczała objawów depresji i uskarżała się wyłącznie na obniżenie nastroju.

2. Nasilenie objawów depresyjnych współwystępowało $\mathrm{z}$ doświadczaniem przykrych emocji, pesymistyczną wizją przyszłości, brakiem rozmowy z bliskimi osobami i deficytem wsparcia społecznego.

3. Niestety badani w niewielkim stopniu deklarowali korzystanie ze specjalistycznej pomocy psychologa czy psychiatry.

4. Z racji częstego współwystępowania depresji i chorób nowotworowych pacjenci onkologiczni powinni być objęci holistyczna opieką, uwzględniającą sytuacją emocjonalną chorych. 


\section{Literatura:}

1. Adamczyk, N., Makara-Studzińska, M., Sidor, K., Pucek, W., Wdowiak, A. (2014). Problemy psychiczne i społeczne występujące u osób z rozpoznaniem nowotworowym, po zabiegach chemioterapii. European Journal of Medical Technologies, 3(4), 67-75.

2. Amirifard, N., Payandeh, M., Aeinfar, M., Sadeghi, M., Sadeghi, E., Ghafarpor, S. (2017). A Survey on the Relationship between Emotional Intelligence and Level of Depression and Anxiety among Women with Breast Cancer. International Journal of Hematology-Oncology and Stem Cell Research, 11(1), 54-57.

3. Baczewska, B., Kropornicka, B., Drozd, C., Olszak, C. (2013). Ocena bólu, lęku i depresji u pacjentów hospitalizowanych z powodu choroby nowotworowej. Przedsiębiorczość i Zarzq̨dzanie, XIV(10), 7-21.

4. Cepuch, G., Wordliczek, J. (2006). Ocena zależności pomiędzy natężeniem bólu a występowaniem lęku i depresji u młodych pacjentów hospitalizowanych z powodu choroby nowotworowej i reumatycznej. Polska Medycyna Paliatywna, 5(2), 44-53.

5. de Walden-Gałuszko, K., Majkowicz, M., Zdun-Ryżewska, A. (2013). Zaburzenia przystosowania do choroby nowotworowej - trudności diagnostyczne zespołów depresyjnych. Psychoonkologia, 1, 10-15.

6. Dębski, R., Kulik, R. (2004). Rozpoznanie i leczenie depresji towarzyszącej nowotworom narządu rodnego. Ginekolog jako lekarz „pierwszego” kontaktu. Wektory Ginekologii, 1, 3-9.

7. Dudek, D., Siwek, M. (2007). Współistnienie chorób somatycznych i depresji. Psychiatria, 4(1), 17-24.

8. Grabińska, K., Szewczyk-Cisek, I., Hernik, P., Mykała-Cieśla, J., Kaziród, D. (2011). Problemy i potrzeby psychosocjalne pacjentów poddanych chemioterapii onkologicznej. Psychoonkologia, 2, 39-47.

9. Jabłoński, M., Furgał, M., Dudek, D., Zięba, A. (2008). Miejsce psychoonkologii we współczesnej psychiatrii. Psychiatria Polska, XLII(5), 749-765.

10. Jarema, M., Rabe-Jabłońska, J. (2011). Psychiatria. Podręcznik da studentów medycyny. Warszawa: Wydawnictwo Lekarskie PZWL.

11. Jarosz, M. (1971). Elementy psychologii lekarskiej i psychopatologii ogólnej. Warszawa: Wydawnictwo Lekarskie PZWL.

12. Kieszkowska-Grudny, A. (2012). Dystres i depresja u chorych na nowotwory - diagnostyka i leczenie. OncoReview, 2(4), 246-252.

13. Kopczyńska-Tyszko, A. (1999). Reakcje emocjonalne chorujących na nowotwór. W: D. Kubacka-Jasiecka, W. Łosiak (red.), Zmagając się z chorobq nowotworową (s. 125-141). Kraków: Wydawnictwo Uniwersytetu Jagiellońskiego.

14. Krawczyk, A. (2013). Zmęczenie i strategie zmagania się z chorobą nowotworową na różnych etapach leczenia. Sztuka Leczenia, 1-2, 21-30.

15. Kulpa, M., Owczarek, K., Stypuła-Ciuba, B. (2013). Przystosowanie psychiczne do choroby nowotworowej a jakość Życia uwarunkowana stanem zdrowia u chorych onkologicznych. Medycyna Paliatywna, 3, 106-113.

16. Malicka, I., Szczepańska, J., Anioł, K., Rymaszewska, J., Woźniewski, M. (2009). Zaburzenia nastroju i strategie przystosowania do choroby u kobiet leczonych operacyjnie z powodu nowotworu piersi i narządów rodnych. Współczesna Onkologia, 13(1), 41-46.

17. Mansano-Schlosser, T.C., Ceolim, M.F., Valerio, T.D. (2017). Poor sleep quality, depression and hope before breast cancer surgery. Applied Nursing Research, 34, 7-11. https://doi.org/10.1016/j.apnr.2016.11.010

18. Massie, M.J. (2004). Prevalence of depression in patients with cancer. Journal of the National Cancer Institute, 32, 57-71. https://doi.org/10.1093/jncimonographs/lgh014

19. Nmeth, K., Kállai, J., Tiringer, I., Mangel, L., Farkas, S., Dér, A., Balázs, P., Szabó, I., Pakai, A. (2011). The relationship of coping mechanisms and social support among Hungarian women suffering from malignant breast cancer. New Medicine, 15(1), 26-29.

20. Nowicki, A., Ostrowska, Ż. (2008). Akceptacja choroby przez chore po operacji raka piersi w trakcie leczenia uzupełniającego. Polski Merkuriusz Lekarski, 24(143), 403-407.

21. Nowicki, A., Rządkowska, B. (2005). Depresja i lęk u chorych z nowotworami złośliwymi. Współczesna Onkologia, 9(9), 396-403.

22. Ohnishi, H. (2011). Mental distress in cancer patients. Masui, 60(9), 1024-1031.

23. Olszewski, W. (2006). Badania przesiewowe w kierunku nowotworów. W: M. Krzakowski (red.), Onkologia Kliniczna (s. 53-60). Warszawa: Borgis.

24. Orońska, A. (2004). Dobra kontrola objawów nadrzędnym zadaniem opieki paliatywnej. Polska Medycyna Rodzinna, 6(3), 849-855.

25. Pawlik, M., Karczmarek-Borowska, B. (2013). Akceptacja choroby nowotworowej u kobiet po mastektomii. Przegląd Medyczny Uniwersytetu Rzeszowskiego i Narodowego Instytutu Leków w Warszawie, 2, 203-211.

26. Rolińska, A., Furmaga, O., Kwaśniewski, W., Makara-Studzińska, M. (2011). Zaburzenia psychiczne w przebiegu choroby nowotworowej. Current Problems of Psychiatry, 12(4), 546-549. 
27. Rymaszewska, J. (2008). Reakcja adaptacyjna, lęk, depresja. W: K. Krzemieniecki (red.), Leczenie wspomagające w onkologii (s. 235-243). Poznań: Termedia Wydawnictwa Medyczne.

28. Sęk, H., Cieślak, R. (2004). Wsparcie społeczne, stres i zdrowie. Warszawa: Wydawnictwo Naukowe PWN.

29. Sharpe, M., Strong, V., Allen, K. (2004). Major depression in outpatients attending a regional cancer center: screening and unmet treatment needs. British Journal of Cancer, 90, 314-320. https://doi.org/10.1038/sj.bjc.6601578

30. Sobieralska-Michalak, K., Kowalska, J., Tudorowska, M. (2016). Rodzaje zabiegu a lęk, depresja i przystosowanie do choroby u kobiet z rozpoznanym rakiem piersi. Polskie Forum Psychologiczne, 21(3), 432446.

31. Stępień, A., Trypka, E. (2012). Zaburzenia psychicznie u chorych na nowotwory w wieku podeszłym. Onkologia w Praktyce Klinicznej, 8(2), 45-51.

32. Stutzman, H., Abraham, S. (2017). ACorrelational Study of SpiritualWell-being and Depression in the Adult Cancer Patient. Health Care Manager, 36(2), 164-172. https://doi.org/10.1097/HCM.0000000000000153

33. Szwat, B., Słupski, W., Krzyżanowski, D. (2011). Sposoby radzenia sobie z chorobą nowotworową a poczucie depresji i nasilenie bólu u chorych objętych opieką paliatywną. Pielęgniarstwo Zdrowie Publiczne, 1(1), 35-41.

34. Ślubowska, M., Ślubowski, T. (2008). Problemy psychosocjalne w raku piersi. Psychoonkologia, 12, 14-25.

35. Zając, T. (2014). Struktura agresji i kontrola emocji u osób z rozpoznaniem depresji. Psychiatria i Psychoterapia, 10(4), 16-29.

36. Zawadzki, B., Popiel, A., Pragłowska, E. (2009). Charakterystyka psychometryczna polskiej adaptacji Kwestionariusza Depresji BDI-II Aarona T. Becka. Psychologia-Etiologia-Genetyka, 19, 71-95.

37. Zielińska-Więczkowska, H., Betłakowski, J. (2010). Jakość życia pacjentów z chorobą nowotworową poddanych chemioterapii. Współczesna Onkologia, 14, 276-280. https://doi.org/10.5114/wo.2010.14437 